\title{
Self-Instruction Technique in Group Counseling to Reduce Students' Academic Procrastination Behavior
}

\author{
Rikas Saputra1, Yenni Lidyawati ${ }^{2}$ \\ Universitas Islam Negeri Raden Fatah, Indonesia ${ }^{1}$ \\ Universitas Sriwijaya, Indonesia ${ }^{2}$ \\ @rikassaputra9@gmail.com ${ }^{1}$
}

Article Information:

Received March 2, 2019

Revised March 29, 2019

Accepted April 12, 2019

Keywords: self-instruction; academic procrastination; group counseling

\section{Abstract}

The purpose of this study was to determine the effectiveness of selfinstruction technique in group counseling to reduce academic procrastination behavior. Purposive sampling technique was administered followed then by random assignment to determine the participants. The scale which is used 44 items from the Procrastination Assessment Scale for Students (PASS) that had previously been adapted and tested for the validity and reliability with Cronbach alpha 0.91 . From the data, the score of academic procrastination behavior was obtained. Then it was categorized into three categories high, moderate, and low academic procrastination. The pretest posttest control group design was applied to 14 students. Based on the independent $t$-test result, after being treated with self-instruction technique in group counseling, there were differences in the pretest mean of 84.00 and the posttest mean of 69.28 . These results indicate a decrease in academic procrastination approximately 14.71, meaning that academic procrastination through the self-instruction technique decreased by $17.51 \%$. Thus, this research shows that group counseling self-instruction technique effectively reduces academic procrastination behavior.

\section{INTRODUCTION}

Adolescence is a time of turmoil and faces many problems, challenges, and conflicts in the search for identity (Bakhrudin, 2017). When someone is entering adolescence, it is a period of transition from childhood to adulthood (Habsy, 2018). When young people are not able to cope with stress-causing sources adaptively, it will develop into pathology (Geldard \& Geldard, 2009). This is related to Rahardjo, Juneman, \& Setiani (2013) research which states that anxiety and stress have contributed significantly in creating academic procrastination, especially the combination of both which adds a stronger effect to procrastination.

Academic procrastination is a postponing activity in academic goals to the point where optimal performance becomes impossible and resulting a state of distress (Jiao, DaRosVoseles, Collins, \& Onwuegbuzie, 2012). Academic procrastination is a leading and potentially maladaptive behavior for many schools often causing distress (Azar, 2013). In addition, findings of Flett, Stainton, Hewitt, Sherry, \& Lay (2012) show that procrastination experience has a unique contribution to increasing distress and stress. Frankton (2014) argues that academic procrastination is a matter where someone knows what to do, but postpones doing it, looking for reasons to do other things instead. Postpone also involves feeling terrible

How to cite:

E-ISSN:

Published by:

Available online:
Saputra, R. \& Lidyawati, L. (2019). Self-Instruction Technique in Group Counseling to Reduce Students' Academic Procrastination Behavior. Islamic Guidance and Counseling Journal, 2(2). 49-55. https://doi.org/10.25217/igcj.v2i2.420

2614-1566

Institut Agama Islam Ma'arif NU (IAIMNU) Metro Lampung

https://journal.iaimnumetrolampung.ac.id/index.php/igcj 
when wanting to do something but choose not to do it. If not doing a good job, making excuses is a commonly manifestation of this problem. From the various expert opinions, academic procrastination is a failure to complete academic assignments without the expectation of being resolved in a certain period of time, there is no purpose, and there is no optimism in doing it. This potentially create maladaptive particularly for the perpetrators themselves.

Grunschel, Schwinger, Steinmayr, \& Fries (2016) state that the use of motivation regulation strategies had a significant positive indirect effect on student academic performance and cognitive well-being through academic procrastination. However, avoiding self-talk performance strategy has a significant negative direct effect on a student's academic achievement and well-being through academic procrastination. Thus this strategy does not seem to be recommended for students. This study provides insights into a motivational regulatory mechanism that influences student academic procrastination, academic achievement, and well-being. Most of previous study discuss the types of adult age and the vocational world. Meanwhile, this study will focus on the perspective of adolescents.

The self-instruction approach is an exercise to improve self-control by using selfverbalization as stimulation and strengthening during treatment. Self-instruction technique uses positive verbal expressions to reduce negative thoughts and in an effort to increase control of themselves through their minds (Tang \& Harvey, 2006). In this self-instruction technique, there are cognitive strategies that can be used, such as self-verbalization or self-talk which aims to guide someone to overcome the problems they face (Erford, 2016). The application of self-instruction technique to reduce students' off-task behavior shows the results of changes instability before and after being given the treatment (Fatimah, 2014). Grunschel et al. (2016) study reveals the causes and effects of academic procrastination in campuses of two German universities. As a result, the reason for the subjects doing academic procrastination was because of internal and external factors.

Cognitive behavior therapy is a psychotherapy approach used by counselors or therapists to help individuals in a positive direction. Various variations in the technique of changing cognition, emotion and behavior become the most important part in Cognitive Behavior Therapy. This method develops according to the needs of students, where the counselor is active, directive, time-limited, structured and student-centered (McLeod, 2013). Self-instruction is one of the techniques of the cognitive behavior therapy approach which involves identifying a person's dysfunctional beliefs and turning them into more realistic ones, and involving behavioral modification techniques (Bos, Muris, Mulkens, \& Schaalma, 2006).

In counseling, the Cognitive Behavioral Therapy group essentially focuses on how to positively reconstruct the counselee's way of thinking and find problem-solving strategies to overcome maladaptive behavioral problems (trauma, anxiety, etc.) and also develop a relationship and respond to events in daily life. Cognitive behavioral therapy is oriented towards problem-solving with therapy that is centered on the "here and now" situation which sees individuals as important decision-makers about the goals or problems that will be solved in the therapy process (Trijayanti, Nurihsan, \& Hafina, 2019). In this way, the counselee is as the therapist's partner in overcoming the problem and with an adequate understanding of the techniques used to solve the problem.

Various study had been conducted to investigate the academic procrastination, as stated before. However, the authors found the limitations of the research carried out were limited to obtaining information about the causes and consequences of procrastination so that it had not include the level of giving intervention. Therefore, the authors gave suggestions to conduct further research related to handling academic procrastination with various strategies that can be chosen, to overcome negative and dysfunctional cognitive influences. Counselors could use cognitive restructuring methods, self-instruction, and relaxation exercises. 
Of all the reasons described above, the self-instruction technique in group counseling is important to be investigated in particularly to reduce students' academic procrastination behavior. Related to the description above, thus an experimental research effort was conducted to determine the effectiveness of self-instruction group counseling technique to reduce academic procrastination behavior. The purpose of this study is to determine the effectiveness of the counseling group of self-instruction technique on academic procrastination behavior.

\section{METHODS}

The method used in this study was Pretest-Posttest Control Group Design. Research samples were determined using a purposive sampling technique followed by random assignment. The data collection method used a Likert scale. The scale used was 44 items adapted from the Procrastination Assessment Scale for Students (PASS) made by Solomon \& Rothblum (1984).

To determine the feasible of adapted instruments, the authors asked for linguist experts to translate the instrument to Bahasa Indonesia, and also back translate to verify whether the translation was done correctly. It then was submitted to Bahasa Indonesia linguist experts. To check the construct of the instrument, it was submitted to experts in the field of psychology and has fulfilled several instruments of feasibility tests, including the validity and reliability tests. The cronbanch alpha score for this research is 0.91 (Erfantinni, Purwanto, \& Japar, 2016).

The results of the academic procrastination behavior score then classified into three categories, namely high academic procrastination, moderate academic procrastination, and low academic procrastination. Low score category $=63-77$, medium score category $=78-$ 92 , and high $=93-107$. From the results of the data calculation that has been done, it can be seen that from 30 students of class VIII, there were 5 students who entered the category of high academic procrastination behavior, 21 students in the moderate category and 4 students in the low category. From the measurement data, seven students for each group were taken as research subjects in the self-instruction experimental and the control group.

Of the seven subjects in each selected group, there were students in the high, medium and low academic procrastination behavior categories. Then treatment to the self-instruction experimental group and the control group were administered. After being given treatment, the posttest was conducted to determine the effectiveness of the treatment results that had been carried out in both groups.

The results of data analysis in this study consisted of two parts, namely pretest data analysis and posttest data analysis. Analysis of pretest data was tested by applying SPSS using the Kolmogorov-Smirnov test for normality testing and using the Levene Statistic Test for homogeneity tests. While to analyze the posttest data analysis the Independent t-test was used.

\section{RESULTS AND DISCUSSION}

To determine the effectiveness of counseling for self-instruction and control groups in reducing academic procrastination behavior, analysis of the posttest data using the Independent t-test which was previously tested using assumptions were conducted.

The posttest results to reduce academic procrastination obtained a significant value of the normality test $0.200>0.05$, so it can be concluded that the two groups were normally distributed. The significant value of the homogeneity test is $0.074>0.05$ so it can be concluded that the results of testing to reduce academic procrastination in both groups are homogeneous. For the independent t-test, the results of data analysis can be seen in Table 1 . 
Based on the table above, it shows that the group that received treatment experienced a decline in academic procrastination behavior while the control group did not experience a decline in it. Thus it can also be concluded that the self-instruction technique is effective in reducing academic procrastination behavior.

\begin{tabular}{|c|c|c|c|c|c|}
\hline & \multicolumn{2}{|c|}{ Pretest } & \multicolumn{2}{|c|}{ Posttest } & \multirow{2}{*}{$\mathbf{t}$} \\
\hline & M & SD & $\mathbf{M}$ & SD & \\
\hline Self-Instruction Group & 84.00 & 10.00 & 69.29 & 4.68 & 0.004 \\
\hline Control Group & 76.00 & 13.00 & 93.00 & 12.80 & 0.030 \\
\hline
\end{tabular}

Table 1. Results of final data analysis

The results of the scores on the counseling group self-instruction technique to reduce students' academic procrastination behavior obtained the average pretest results of 84.00 and the posttest average of 69.28. This shows the decrease difference in student academic procrastination is 14.71 meaning that academic procrastination with the self-instruction technique dropped by $17.51 \%$ with t-value $0.004<0.01$ which the difference is statistically significant.

The results of the scores in the control group without treatment obtained average pretest results 76.00 and the posttest average 93.00. This shows an increase in academic procrastination behavior by 17.00 meaning that academic procrastination in the control group has increased by $22.36 \%$ with t-value $0.030>0.01$ which the difference is not statistically significant.

This study aims to determine the effectiveness of self-instruction technique in group counseling to reduce academic procrastination behavior. Academic procrastination itself is divided into three categories, namely high, medium, and low academic procrastination which in each counseling group there exist each of these categories.

In addition to the counseling group, this study also looked at the students' academic procrastination behavior in the control group to compare the extent of the effectiveness of group counseling conducted. In the self-instruction technique group, the mean results from pretest to posttest dropped from 84.00 to 69.28 , this indicates that there is a significant decrease in academic procrastination behavior. From these results, there are significant changes after participating in the self-instruction technique counseling group. The decrease in academic procrastination behavior does not occur by itself but always takes place in group interactions with self-instruction technique that has been implemented. Therefore, it is very necessary to apply self-instruction technique in group counseling to reduce academic procrastination behavior.

In addition to the results obtained in this study, there was a previously conducted research on self-instruction by Suryaningrum, Prihartanti, \& Hertinjung (2016) who examined the training of self-esteem through self-instruction methods to improve disabled students' self-confidence. The result indicates that training of self-esteem through self-instruction can improve one's self-confidence, this result along with Chandra, Wibowo, \& Sunawan (2019) findings. Besides being able to be used to improve self-esteem, self-instruction technique has also been tested on various kinds of problems and proven effective in overcoming these problems, for example in the research carried out by Weidler (1985) who used self-instruction as an intervention method to help people experiencing failure in metacognition. It is also proven that self-instruction can also improve one's metacognitive abilities. Lange, Richard, Gest, Vries, \& Lodder (1998) have also proven the effectiveness of self-instruction technique for people suffering from emotional turmoil. Self-instruction technique has been carried out by another similar research done by Bryant \& Budd (1982). Self-instruction is a procedure designed to improve self-control independently through verbal statements to encourage, guide 
and maintain nonverbal actions. From the various things described above, it is clear that the self-instruction technique is effective as a solution to academic procrastination behavior.

Implication of this study is guidance and counseling teachers/counselors at schools can utilize the results of this research by studying cognitive behavior therapy approaches and selfinstruction technique to reduce academic procrastination behavior.

This study is only limited to reducing academic procrastination, for further research it is suggested to use self-instruction technique in group counseling to reduce stress and anxiety. This research is expected to be a step to perfect various limitations of the research that has been conducted before.

\section{CONCLUSIONS}

Pursuant to the result of this research, it can be concluded that the self-instruction technique in group counseling activities have been proved effective to reduce academic procrastination behavior. The procrastination treated with self-instruction in group counseling decreased, otherwise increased in control group.

\section{ACKNOWLEDGMENTS}

The authors present their sincere appreciation goes to Dr. Edy Purwanto, M.Si. and Dr. Awalya, M.Pd., Kons. for supervision on the research draft and adaptation of research instrument. The authors thanked Prof. Dr. Mungin Edi Wibowo M.Pd., Kons., Sunawan, Ph.D., Prof. Dr. Rer. nat Wahyu Hardyanto, M.Sc., and Prof. Dr. Achmad Slamet, M.Sc. as the examiners who had given critics and suggestions to authors as well as State Junior High School 24 Palembang which allows the authors to conduct research. Acknowledgement also extended to all students who participated in the initial survey, experiment group, and control group as they voluntarily participate in the research.

\section{AUTHOR CONTRIBUTION STATEMENTS}

RS made the draft of this manuscript, collected data, and conducted the control and experiment group counseling. YL helped RS to draft and wrote the manuscript. Both authors had approved the final manuscript.

\section{REFERENCES}

Azar, F. S. (2013). Self-efficacy, achievement motivation, and academic procrastination as predictors of academic performance. US-China Education Review, 3(11), 847-857. Retrieved from Google Scholar

Bakhrudin, H. A. (2017). Model Konseling Kelompok Cognitive Behavior untuk Penanganan Self-esteem Siswa SMK. Jurnal Bimbingan Dan Konseling Terapan, 1(2). http://dx.doi.org/10.30598/jbkt.v1i2.144

Bos, A. E. R., Muris, P., Mulkens, S., \& Schaalma, H. P. (2006). Changing self-esteem in children and adolescents: a roadmap for future interventions. Netherlands Journal of Psychology, 62(1), 26-33. https://doi.org/10.1007/BF03061048

Bryant, L. E., \& Budd, K. S. (1982). Self-Instructional Training to Increase Independent Work Performance in Preschoolers. Journal of Applied Behavior Analysis, 15(2), 259271. https://doi.org/10.1901/jaba.1982.15-259

Chandra, E. K., Wibowo, M. E., \& Sunawan, S. (2019). Cognitive Behaviour Group Counseling with Self-Instruction and Cognitive Restructuring Techniques to Improve Students' Self-Confidence. Islamic Guidance and Counseling Journal, 2(1), 11-17. https://doi.org/10.25217/igcj.v2i1.305 
Erfantinni, I. H., Purwanto, E., \& Japar, M. (2016). Konseling Kelompok Cognitive-Behavior Therapy dengan Teknik Cognitive Restructuring untuk Mereduksi Prokrastinasi Akademik. Jurnal Bimbingan Konseling, 5(2), 119-125. Retrieved from Google Scholar

Erford, B. T. (2016). Professional School Counseling: A Handbook of Theories, Programs, and Practices. Third Edition. Retrieved from Google Scholar

Fatimah, F. N. (2014). Penerapan Teknik Self-Instruction untuk Mengurangi Perilaku Off Task Siswa Kelas X di SMK Negeri 12 Surabaya. Jurnal BK UNESA, 4(1). Retrieved from Google Scholar

Flett, G. L., Stainton, M., Hewitt, P. L., Sherry, S. B., \& Lay, C. (2012). Procrastination Automatic Thoughts as a Personality Construct: An Analysis of the Procrastinatory Cognitions Inventory. Journal of Rational-Emotive \& Cognitive-Behavior Therapy, 30(4), 223-236. https://doi.org/10.1007/s10942-012-0150-z

Frankton, J. (2014). Ticking Away - How to Overcome Laziness and Procrastination. Retrieved from Google Scholar

Geldard, K., \& Geldard, D. (2009). Counselling Adolescents: The Proactive Approach for Young People. Retrieved from Google Scholar

Grunschel, C., Schwinger, M., Steinmayr, R., \& Fries, S. (2016). Effects of using motivational regulation strategies on students' academic procrastination, academic performance, and well-being. Learning and Individual Differences, 49, 162-170. https://doi.org/10.1016/j.lindif.2016.06.008

Habsy, B. A. (2018). Model bimbingan kelompok PPPM untuk mengembangkan pikiran rasional korban bullying siswa SMK etnis Jawa. Jurnal Pendidikan (Teori Dan Praktik), 2(2), 91-99. http://dx.doi.org/10.26740/jp.v2n2.p91-99

Jiao, Q. G., DaRos-Voseles, D. A., Collins, K. M. T., \& Onwuegbuzie, A. J. (2012). Academic procrastination and the performance of graduate-level cooperative groups in research methods courses. Journal of the Scholarship of Teaching and Learning, 11(1), 20. Retrieved from Google Scholar

Lange, A., Richard, R., Gest, A., Vries, M. D., \& Lodder, L. (1998). The Effects of Positive Self-Instruction: A Controlled Trial. Cognitive Therapy and Research, 22(3), 225-236. https://doi.org/10.1023/A:1018740725281

McLeod, J. (2013). An Introduction to Counselling. Retrieved from Google Scholar

Rahardjo, W., Juneman, J., \& Setiani, Y. (2013). Computer Anxiety, Academic Stress, and Academic Procrastination on College Students. Journal of Education and Learning (EduLearn), 7(3), 147. https://doi.org/10.11591/edulearn.v7i3.179

Solomon, L. J., \& Rothblum, E. D. (1984). Academic procrastination: Frequency and cognitive-behavioral correlates. Journal of Counseling Psychology, 31(4), 503-509. https://doi.org/10.1037/0022-0167.31.4.503

Suryaningrum, D. U., Prihartanti, N., \& Hertinjung, W. S. (2016). Efektifitas Pelatihan Harga Diri dengan Metode Instruksi Diri untuk Meningkatkan Kepercayaan Diri pada Siswa BBRSBD Surakarta (PhD Thesis, Universitas Muhammadiyah Surakarta). Retrieved from Google Scholar 
Tang, N. K. Y., \& Harvey, A. G. (2006). Altering misperception of sleep in insomnia: Behavioral experiment versus verbal feedback. Journal of Consulting and Clinical Psychology, 74(4), 767-776. https://doi.org/10.1037/0022-006X.74.4.767

Trijayanti, Y. W., Nurihsan, J., \& Hafina, A. (2019). Gestalt Counseling with Empty Chair Technique to Reduce Guilt among Adolescents at Risk. Islamic Guidance and Counseling Journal, 2(1), 1-10. https://doi.org/10.25217/igcj.v2i1.302

Weidler, S. D. (1985). The Use of Cognitive Self-Instruction as an Intervention for Metacognitive Failure. Retrieved from Google Scholar

Copyright Holder :

(C) Saputra, R. \& Lidyawati, L. (2019)

First Publication Right :

(c) Islamic Guidance and Counseling Journal

This article is under:

(ㅇ) (1) (2) 